Pak. j. sci. ind. res. Ser. A: phys. sci. 201255 (1) 1-7

\title{
Potential for Underground Gasification of Pakistani Lignite Coal
}

\author{
Shoukat Parvez ${ }^{\mathrm{a}}$, Gulzar Hussain Jhatial ${ }^{\mathrm{b} *}$, Anila Sarwar ${ }^{\mathrm{b}}$, Syed Kabir Shah \\ Santosh Kumar ${ }^{\mathrm{b}}$, Naseem Ahmed ${ }^{\mathrm{b}}$ and Syed Najam UI Islam ${ }^{\mathrm{b}}$ \\ ${ }^{a}$ PCSIR Head Office, Constitution Avenue, Islamabad, Pakistan \\ ${ }^{\mathrm{b}}$ Fuel Research Centre, Off University Road, Karachi-75280, Pakistan
}

(received August 9, 2011; revised October 31, 2011; accepted November 2, 2011)

\begin{abstract}
Laboratory scale process of underground gasification of Pakistani lignite has been performed to check the potential of the Pakistani coal for gasification. High permeability and low swelling index of coal are desirable properties for UCG. In Pakistani lignite both properties are found and in case of lignite and brown coal, natural permeability provides adequate linkage. The proximate and ultimate compositions of the samples show that it is of low quality coal with high volatile matter. Coal has been converted into syngas and utilized as the substitute of natural gas and for power generation.
\end{abstract}

Keywords: underground coal gasification, syngas, Pakistani lignites, Thar coal

\section{Introduction}

Coal is the most abundant fossil fuel in Pakistan. After the discovery of the huge coal deposits of 175.5 billion tonnes in an area of 9,500 sq. km in Tharparkar District of Sindh, Pakistan has got a significant position in the list of coal rich countries (GSP, 2001). Unfortunately the huge reserves are not exploited yet, while Pakistani lignites are suitable for underground coal gasification (UCG) and can be used for power generation as most of the countries are using lignite having suitable calorific value (CV) (Table 1). Government of Pakistan is now progressively looking to its indigenous coal reserves not only as a solution to its dependence on imports to fuel to strengthen its economy but also as an alternative fuel of natural gas and power generation in future.

Underground coal gasification has a number of economical and environmental aspects as compared to conventional use of coal (Klimenko, 2009). At present classical mining is the most common technology for the coal extraction irrespective of its well known disadvantages. The preliminary studies show that the extraction of the coal via classical mining methods is not economical at Thar as its moisture contents are extremely high (40-50\%) (Brockway and Huggins, 1991). Government of Pakistan is now initiating seriously

*Author for correspondence; E-mail: frc-pcsir@yahoo.com towards clean coal technologies, especially UCG. Underground coal gasification enables us to extract coal reserves that would not normally be mined.

Underground coal gasification is the in-situ conversion of coal into product of combustible gases. It is a complex process involving chemical reactions, heat and mass transfer and complex flow dynamics (Guo et al., 2008; GasTech, Inc., 2007). UCG utilizes injection and production wells drilled from the surface and linked together in the coal seam. Once linked, air and / or oxygen are injected. The coal is then ignited in a controlled manner to produce hot, combustible syngas (a mixture of $\mathrm{CH}_{4}, \mathrm{CO}, \mathrm{CO}_{2}$ and $\mathrm{H}_{2}$ ) which are captured by the production wells (Fig. 1). The syngas is brought to the surface and cleaned for power generation and liquid hydrocarbon fuel. It can also be used for the generation of other valuable chemical products (Fig. 2).

Chemically, UCG is a complex processes; where following reactions take place:

$$
\begin{array}{ll}
\text { Combustion of carbon } & \mathrm{C}+\mathrm{O}_{2} \rightarrow \mathrm{CO}_{2} \\
\text { Partial oxidation } & \mathrm{C}+1 / 2 \mathrm{O}_{2} \rightarrow \mathrm{CO} \\
\text { Oxidation } & \mathrm{C}+1 / 2 \mathrm{O}_{2} \rightarrow \mathrm{CO}_{2} \\
\text { Water gas shift } & \mathrm{C}+1 / 2 \mathrm{H}_{2} \mathrm{O} \rightarrow \mathrm{CO}_{2}+\mathrm{H}_{2} \\
\text { Methanation } & \mathrm{CO}+1 / 23 \mathrm{H}_{2} \rightarrow \mathrm{CO}_{4}+\mathrm{H}_{2} \mathrm{O} \\
\text { Hydrogenization } & \mathrm{C}+2 \mathrm{H}_{2} \rightarrow \mathrm{CH}_{4} \\
\text { Boudouard's reaction } & \mathrm{C}+\mathrm{CO}_{2} \rightarrow 2 \mathrm{CO} \\
\text { Reaction steam-carbon } \mathrm{C}+\mathrm{H}_{2} \mathrm{O} \rightarrow \mathrm{CO}+\mathrm{H}_{2} \\
\text { Loosening of hydrogen } 2 \mathrm{H} \text { (in coal) } \rightarrow \mathrm{H}_{2} \text { (gas) }
\end{array}
$$




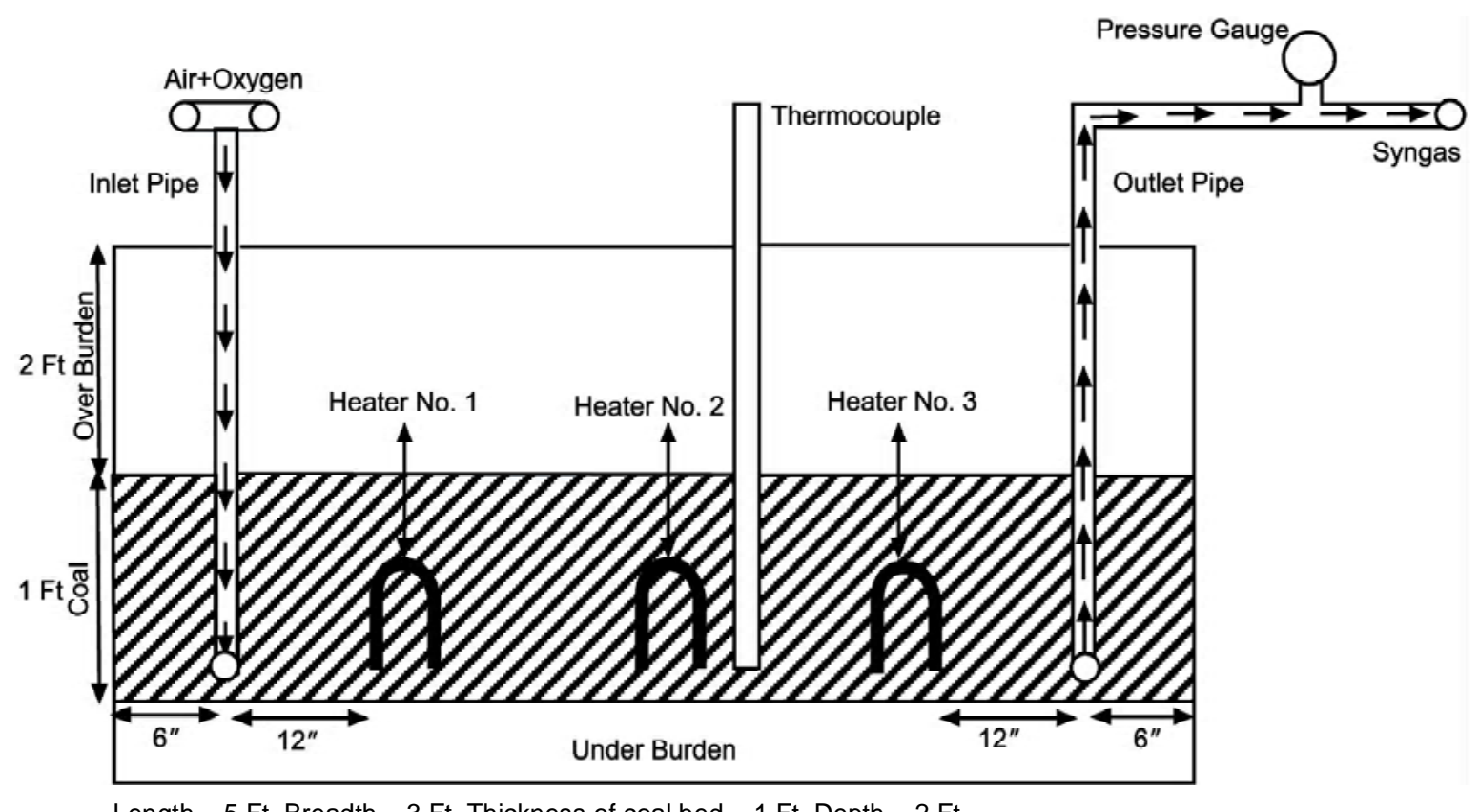

Length $=5 \mathrm{Ft}$, Breadth $=3 \mathrm{Ft}$, Thickness of coal bed $=1 \mathrm{Ft}$, Depth $=2 \mathrm{Ft}$

\begin{tabular}{lll}
\hline \hline $\begin{array}{l}\text { Temperature 200-550 } \\
\text { Drying pyrolysis }\end{array}$ & $\begin{array}{l}\text { Temperature 200-900 } \\
\text { Reduction zone }\end{array}$ & $\begin{array}{l}\text { Temperature } 900{ }^{\circ} \mathrm{C} \\
\text { Oxidation zone }\end{array}$ \\
\hline Coal $\rightarrow \mathrm{CH}_{4}+\mathrm{H}_{2} \mathrm{O}$ & $\mathrm{C} \rightarrow \mathrm{H}_{2} \mathrm{O}+\mathrm{CO}+\mathrm{H}_{2}$ & $\mathrm{C}+\mathrm{O}_{2} \rightarrow \mathrm{CO}_{2}$ \\
$\mathrm{CO}+\mathrm{CO}_{2}$ & $\mathrm{CO}_{2}+\mathrm{C} \rightarrow 2 \mathrm{CO}$ & $\mathrm{C}+1 / 2 \mathrm{O}_{2} \rightarrow \mathrm{CO}$ \\
$\mathrm{H}_{2}+\mathrm{C}$ & $\mathrm{CO}+\mathrm{H}_{2} \mathrm{O} \leftrightarrows \mathrm{CO}_{2}+\mathrm{H}_{2}$ & $\mathrm{C}+1 / 2 \mathrm{O}_{2} \rightarrow \mathrm{CO}_{2}$ \\
Hydrocarbon & $\mathrm{CO}+2 \mathrm{H}_{2} \rightarrow \mathrm{CH}_{4}$ & $\mathrm{Coal}+\mathrm{O}_{2} \rightarrow \mathrm{CO}_{2}+\mathrm{CO}+\mathrm{H}_{2} \mathrm{O}$ \\
\hline
\end{tabular}

Fig. 1. Schematic representation of underground gasification of coal.

A number of theoretical and experimental studies concerning UCG have been conducted in many countries, resulting in great progress in this field (GasTech, Inc., 2007; Creedy and Garner, 2004). The aim of the present work is to study the potential of underground coal gasification for Pakistani lignite to exploit Thar coal resources which are either uneconomic to work by conventional extraction by coal mining, or inaccessible due to depth, geology or other mining and safety considerations.

\section{Materials and Methods}

Laboratory scale underground coal gasification (UCG) was initiated by Lakhra coal as it is easily available. Thar coal and Lakhra Coal both are Pakistani lignite coals and their physical and chemicals properties are similar to each other. The proximate and ultimate composition and major and minor oxides in Thar lignite resembles to Lakhra coal (Table 2 and 3). Therefore,
Table 1. Comparison of calorific value and power generation in different countries

\begin{tabular}{lll}
\hline \hline Country & $\begin{array}{l}\text { Calorific value } \\
\text { (Btu/lb.) }\end{array}$ & $\begin{array}{l}\text { Total power } \\
\text { generation } \\
\text { (MW) }\end{array}$ \\
\hline India & 5,200 & 2,740 \\
Germany & $4,514-11,054$ & 10,289 \\
Hungary & 3,035 & 1,852 \\
Pakistan Thar Coal & $6,200-11,000$ & 0.00 \\
South Africa & 10,293 & 32,200 \\
China & 9,900 & $1.95 \times 10^{9}$ \\
\hline \hline
\end{tabular}

Lakhra coal has been selected for UCG experiment. An area of $6^{\prime} \times 2^{\prime} \times 3^{\prime}$ has been selected for UCG (Fig. 3a). The coal bed of $1^{\prime}$ thickness having $450 \mathrm{~kg}$ of coal has been prepared. An overburden of soil ( 2 ' thickness) was introduced on it. Two adjacent seamless pipes of $6^{\prime}$ length and 1.5" diameter were inserted vertically into 


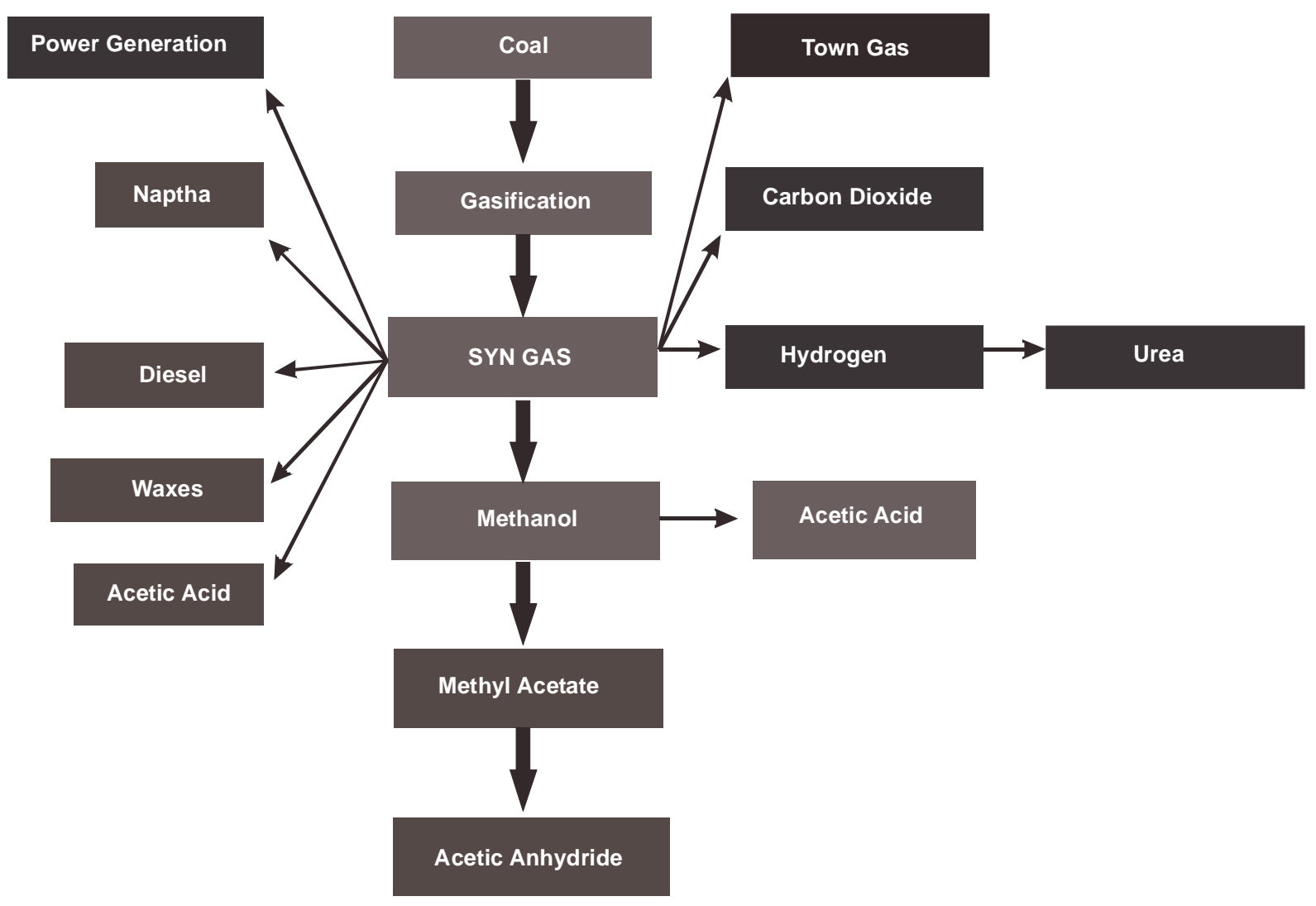

Fig. 2. Refining of syncrude - production of diesel, methanol and petrochemicals.

Table 2. Classification of coal samples

\begin{tabular}{lll}
\hline \hline Parameters & $\begin{array}{l}\text { Lakhra coal } \\
(\%)\end{array}$ & $\begin{array}{l}\text { Thar coal } \\
(\%)\end{array}$ \\
\hline $\begin{array}{l}\text { Proximate composition } \\
\text { Inherent moisture }\end{array}$ & & \\
Volatile matter $^{\mathrm{b}}$ & 25.38 & 45.24 \\
Ash yield $^{\mathrm{a}}$ & 30.21 & 28.38 \\
Fixed carbon $^{\mathrm{a}}$ & 7.21 & 5.20 \\
Ultimate composition $^{\text {Carbon }}{ }^{\mathrm{c}}$ & 37.20 & 21.18 \\
Hydrogen $^{\mathrm{c}}$ & 70.24 & 62.40 \\
Nitrogen $^{\mathrm{c}}$ & 7.98 & 5.22 \\
Sulphur $^{\mathrm{a}}$ & 4.29 & 4.87 \\
Oxygen $^{\mathrm{c}}$ & 3.28 & 2.07 \\
Others $^{\text {GCV }}$ / Btu/lb $_{\text {ASTM Rank }}$ & 14.21 & 25.44 \\
\hline
\end{tabular}

a ar basis = as-received basis; ${ }^{b}$ ad basis = as-determined basis; ${ }^{\mathrm{c}}$ daf basis = dry, ash-free basis; ${ }^{\mathrm{d}} \mathrm{db}$ basis = dry basis; ${ }^{\mathrm{e}} \mathrm{mmf}$ basis = moisture, mineral matter-free basis.
Table 3. Major and minor elements in coal samples

\begin{tabular}{cll}
\hline \hline Oxides & $\begin{array}{l}\text { Lakhra coal } \\
(\%)\end{array}$ & $\begin{array}{l}\text { Thar coal } \\
(\%)\end{array}$ \\
\hline $\begin{array}{c}\text { Major } \\
\mathrm{SiO}_{2}\end{array}$ & 35.24 & 40.21 \\
$\mathrm{Al}_{2} \mathrm{O}_{3}$ & 25.28 & 11.24 \\
Minor & & \\
$\mathrm{Fe}_{2} \mathrm{O}_{3}$ & 20.74 & 18.24 \\
$\mathrm{Na}_{2} \mathrm{O}$ & 1.50 & 1.27 \\
$\mathrm{~K}_{2} \mathrm{O}$ & 0.62 & 0.25 \\
$\mathrm{MgO}$ & 3.89 & 4.24 \\
$\mathrm{CaO}$ & 15.20 & 13.29 \\
$\mathrm{MnO}_{2}$ & 0.01 & 0.01 \\
\hline \hline
\end{tabular}

the bed as inlet and outlet pipes (Fig. 3b). The connectivity between inlet and outlet pipes was made by passing pressurized oxidants (air 100 psi and oxygen 30-40 psi) into the coal bed. Two electrical heaters of $1000 \mathrm{~W}$ were put into the coal bed. Two thermocouples 


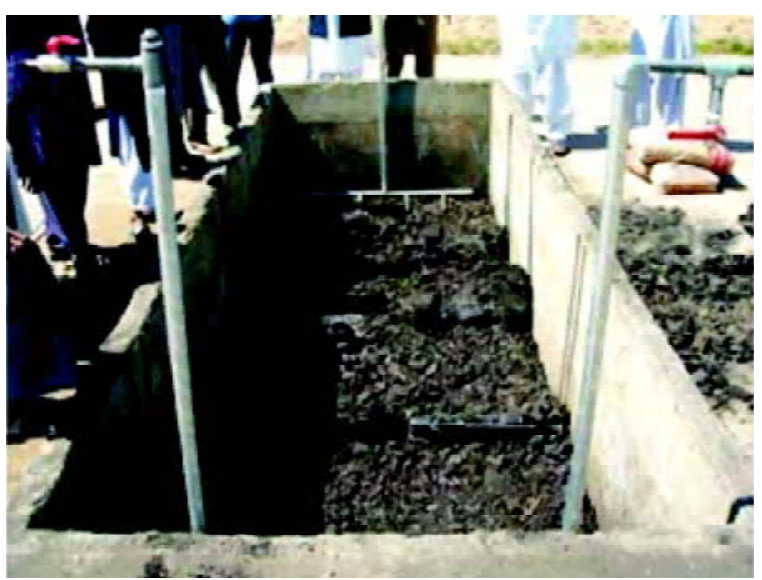

Fig. 3a. Preparation of coal bed measuring $6{ }^{\prime} \times 3^{\prime}$ $x 2^{\prime}$ filling of coal in bed,insertion of pipes, heaters and thermocouple in bed.

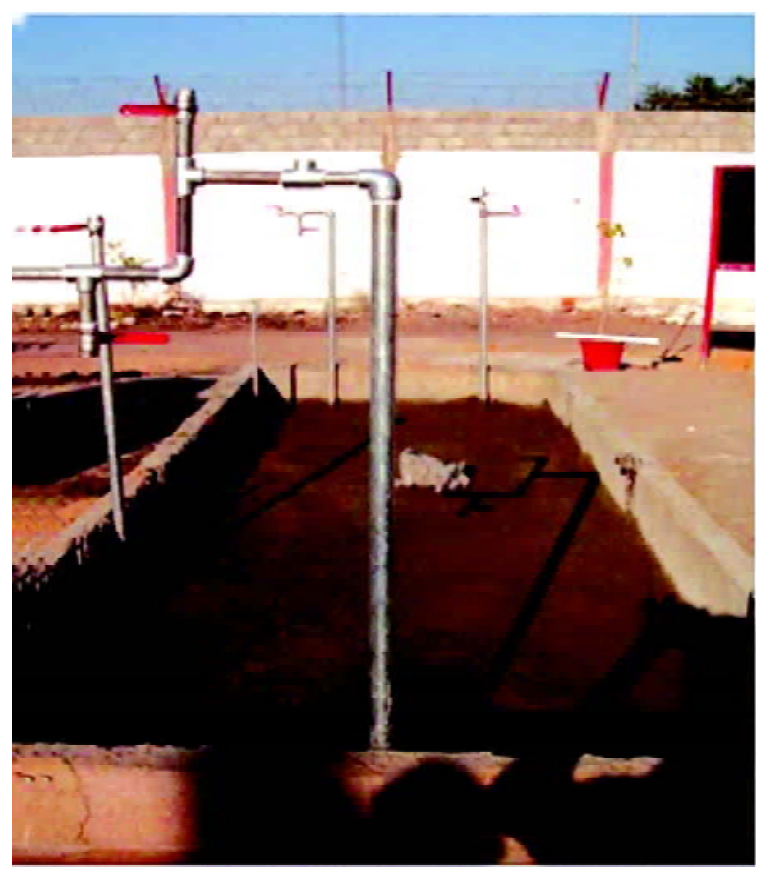

Fig. 3b. Covered bed with installed pipes.

(length $30^{\prime \prime}$, temperature range $0-1800^{\circ} \mathrm{C}$ ) were inserted near inlet and outlet pipes to measure the temperature continuously inside the bed during operation (Fig. 3c). The coal bed was ignited electrically under controlled conditions and combustion gases evolved were collected through the adjacent outlet pipe and analyzed by Flue Gas Analyzer (Testo t 350 XL, Germany) on the spot. Samples were also collected in cylinders (at 7 psi) and analyzed by gas chromatography (GC) using ASTM D-1945 and D-3588. Components of the gas in the

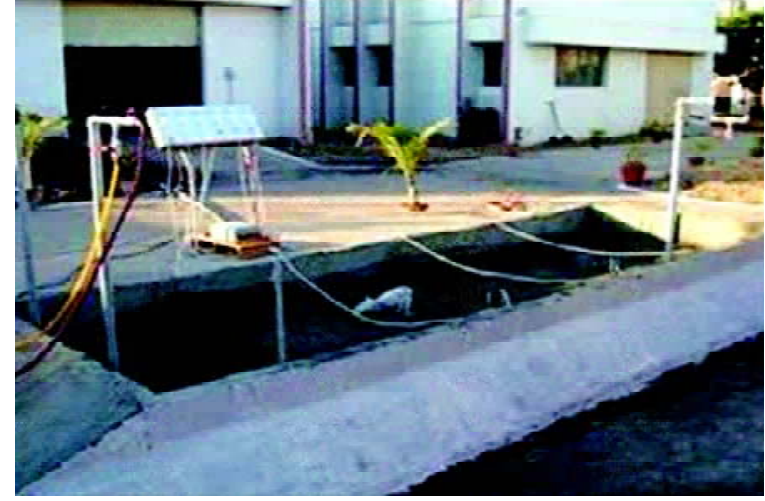

Fig. 3c. Overview of bed with electrification system.

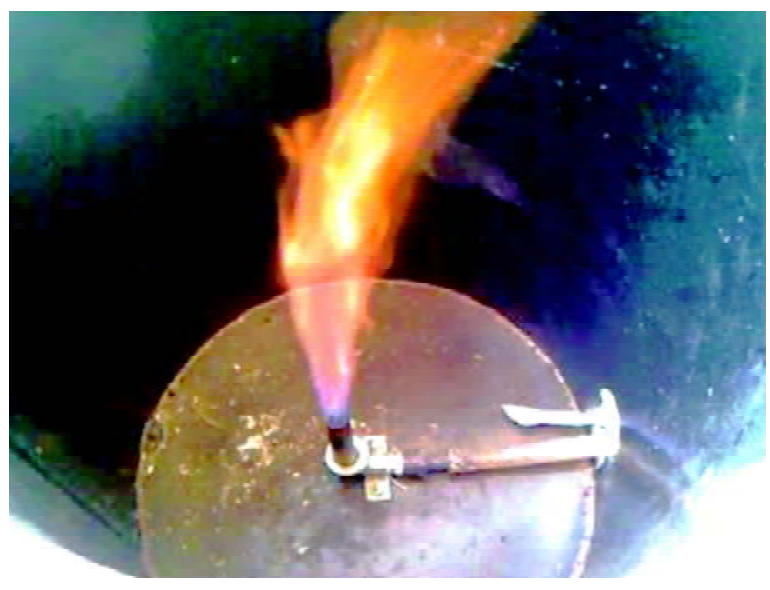

Fig 4. Flame of syngas.

representative scale were physically separated by GC and compared to calibration data contained under identical operating conditions from a reference standard mixture of known composition. The composition of the sample was calculated by comparing the peak areas with the corresponding values obtained with the reference standard.

\section{Results and Discussion}

Lakhra coal is of low rank and Tertiary age. It has some important features in relation to its pyrolysis and gasification characteristics. Firstly, as a class of low rank, the oxygen content of Lakhra coal is high and ranges from about $14 \mathrm{wt} \%$ (daf). The oxygen exists in a wide variety of functional groups. Carboxylic and phenolic are the most important and highly reactive functional groups present at the surface of Lakhra coal. These functional groups are responsible for the dispersion of some metallic species in the coal (James 
and Durrani, 1994). They are also involved in various reactions taking place during pyrolysis and affect the properties of pyrolysis products and char ( $\mathrm{Li}, 2007$; Schafer, 1991). Secondly; Lakhra coal has a significant amount of $\mathrm{Na}, \mathrm{Mg}$, Ca and Fe. These species act as ion exchangeable cations associated with the carboxyl groups forming organic part of the coal or as soluble salts associated with the moisture (Friedmann et al., 2009; Hayashi and Li, 2004; James and Durrani, 1994; Qadeer, 1985). The salt also acts as excellent catalysts for the subsequent char gasification and combustion reactions (Wood and Sancier, 1984). Another significant property of these coals is the significant amount of volatile matter which is responsible for gasification and pyrolysis processes.

In UCG, the use of steam and oxygen is prerequisite in Synthetic Natural Gas production. Coal reacts with steam and oxygen to produce $\mathrm{CO}, \mathrm{CO}_{2}, \mathrm{H}_{2}, \mathrm{CH}_{4}$ and small amounts of other compounds. High permeability and low swelling of coal are desirable properties. Lakhra coal has high permeability as lignites have permeabilities which are about 1000 times higher than the permeabilities of bituminous coals (Schafer, 1991). The natural permeability permits pneumatic linkage without any initial work. In lignite coal natural permeability provides linkage, swelling of coal during gasification plugs the passages available for gas flow. Therefore, Lakhra and Thar coals are suitable for UCG process. After ignition drying and pyrolysis occur at $200-550^{\circ} \mathrm{C}$, reduction of coal occurs in the range of $500-900{ }^{\circ} \mathrm{C}$. While at temperature $>900{ }^{\circ} \mathrm{C}$ oxidation of coal starts. As the result, coal is converted into gaseous products. The composition of raw gas has been shown in Table 4 . Three trial runs were performed to study the composition of syngas. In trial 1 , the syngas has been collected in the presence of 20 psi oxygen pressure. The second sample of gas has been collected at the time when the supply of oxygen was stopped after ignition started. In trial 3, $15 \%$ coal tar has been mixed in coal to study the effect of coal tar on the composition of syngas. It was observed that the pressure of coal tar in coal has reduced the ignition time and increase the stability of flame. The presence of methane gas was confirmed by ignition test. A flame of blue colour with red/orange tip has been obtained on ignition whose length was 6-12 inch. The flame temperature was $400-600{ }^{\circ} \mathrm{C}$ (Fig. 4).

During the experiment syngas was collected in a compressor. The compressor was connected with a gas generator of 2KVA. The generator was connected with a total load of 742 Watt. The details of the total load

Table 4. Analysis of syngas evolved during UCG

\begin{tabular}{|c|c|c|c|c|}
\hline \multirow{2}{*}{$\begin{array}{l}\text { S. } \\
\text { no. }\end{array}$} & \multirow[t]{2}{*}{ Parameters } & \multicolumn{3}{|c|}{ Test result } \\
\hline & & $\begin{array}{l}\text { Trial } 1 \\
(\%)\end{array}$ & $\begin{array}{l}\text { Trial } 2 \\
(\%)\end{array}$ & $\begin{array}{l}\text { Trial } 3 \\
(\%)\end{array}$ \\
\hline 1. & Oxygen & 14.02 & 1.72 & 2.43 \\
\hline 2. & Carbon dioxide & 0.09 & 40.64 & 21.47 \\
\hline 3. & Carbon monoxide & 7.02 & 1.93 & 3.57 \\
\hline 4. & Nitrogen & 53.07 & 48.38 & 57.63 \\
\hline 5. & Methane & 4.94 & 6.06 & 6.32 \\
\hline 6. & Ethane & 2.95 & 0.59 & 0.54 \\
\hline 7. & Propane & 1.43 & 0.52 & 0.39 \\
\hline 8. & iso-butane & Traces & 0.758 & Traces \\
\hline 9. & n-butane & 0.377 & 0.165 & 0.069 \\
\hline 10. & Sulphur dioxide & 410 ppm & 122 ppm & 17 ppm \\
\hline 11. & Hydrogen & 102 ppm & 6364 ppm & $1225 \mathrm{ppm}$ \\
\hline 12. & Nitrogen oxide & $1 \mathrm{ppm}$ & $35 \mathrm{ppm}$ & $2 \mathrm{ppm}$ \\
\hline 13. & Gas gravity & 0.90 & 1.17 & 0.99 \\
\hline 14. & $\begin{array}{l}\text { Gross heating value / Btu/ft }{ }^{3} \text { of dry gas } \\
\text { @ } 14.65 \text { PSI and } 60^{\circ} \mathrm{F}\end{array}$ & $410.45 \mathrm{Btu} / \mathrm{ft}^{3}$ & $95.95 \mathrm{Btu} / \mathrm{ft}^{3}$ & $96.82 \mathrm{Btu} / \mathrm{ft}^{3}$ \\
\hline 15. & $\begin{array}{l}\text { Net heating value/ Btu/ } / \mathrm{t}^{3} \text { of dry gas } \\
\text { @ } 14.65 \mathrm{PSI} \text { and } 60^{\circ} \mathrm{F}\end{array}$ & $375.48 \mathrm{Btu} / \mathrm{ft}^{3}$ & 88.34 Btu/ $/ \mathrm{ft}^{3}$ & 88.67 Btu/ $/ \mathrm{ft}^{3}$ \\
\hline
\end{tabular}



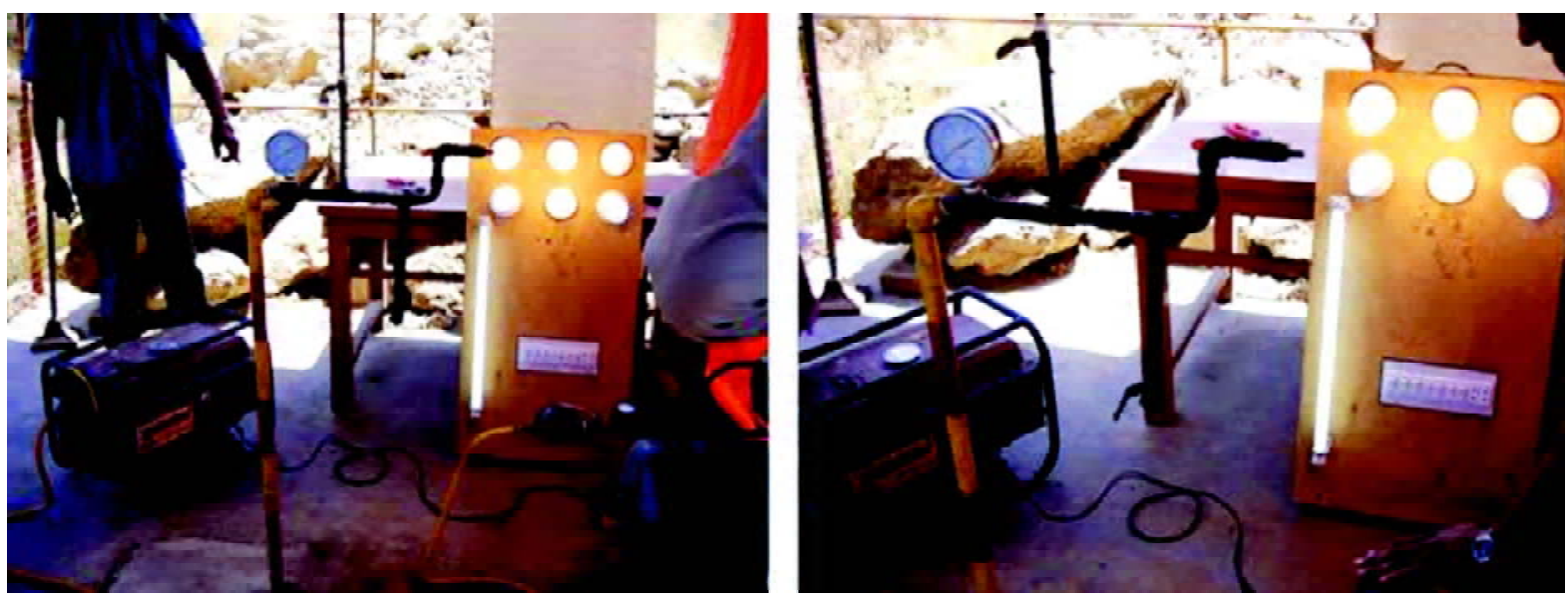

Fig. 5. View of power generation from syngas.

Table 5. Power generation from Lakhra coal

\begin{tabular}{llll}
\hline \hline $\begin{array}{l}\text { S. } \\
\text { no. }\end{array}$ & Items & Quantity & $\begin{array}{l}\text { Power/ } \\
\text { Watt }\end{array}$ \\
\hline 1. & Electric bulb of 200 Watt & 02 & 400 \\
2. & Electric bulb of 100 Watt & 02 & 200 \\
3. & Tube light & 01 & 20 \\
4. & Energy saver of 24 Watt & 01 & 24 \\
5. & Energy saver of 18 Watt & 01 & 18 \\
6. & Pedestal Fan & 01 & 80 \\
\hline & & Total load & 742 \\
\hline \hline
\end{tabular}

are shown in Table 5. The results show that syngas generated from Lakhra coal has the potential for power generation (Fig. 5).

\section{Conclusion}

Underground gasification of Pakistani lignites has great promise for power and fuel production, While UCG appears to be commercially viable in Pakistan as the country has huge reserves of coal. Owing to high oxygen content, high volatile matter, low swelling index and high permeability of Pakistani lignite, it is suitable for gasification process. The selected coal has been converted into gaseous products via pyrolysis and combustion reaction with the release of considerable amount of syngas. The product gas was found to have the potential to use as a substitute of synthetic natural gas. Syngas is a versatile product that can be utilized in efficient power generation transformed into synthetic gas or liquid fuel or and as chemical feed stock. On the basis of similarities between Lakhra and Thar coal it has been concluded that low grade and inaccessible coal reserves of Thar can not only be utilized for power generation but also as the substitute of natural gas. It gives the aspects of the current understanding that have not been thoroughly studied yet for the utilization of Thar coal in the country.

\section{References}

Brockway, D.J., Higgins, R.S. 1991. In: The Science of Victorian Brown Coal, R.A. Durie (ed.), Chapter 5, Butterworth, Oxford, U.K.

Creedy, D.P., Garner, K. 2004. Clean energy from underground coal gasification in China, DTI (Department of Trade and Industry) Cleaner Coal Technology Transfer Programme, Report No. COAL R250 DTI/Pub URN 03/1611, February 2004, London, UK.

Friedmann, J.S., Upadhye, R., Kong, F.M. 2009. Prospects for underground coal gasification in carbon-constrained. World Energy Procedia, 1: 4551-4557.

GasTech, Inc., 2007. Viability of underground coal gasification in the "Deep Coals" of the Power River Basin, Wyoming Business Council, Report 061507. Wyoming, USA.

GSP., USAID. 2001. Thar Coal. GSP and the United States Agency for International Development, Field, http:// www.en.wikipedia.org/wiki/thar coal field.

Guo, X., Tay, H. L., Zhang, S., Li, C.-Z. 2008. Changes in char structure during the gasification of a Victorian brown coal in steam and oxygen at $800^{\circ} \mathrm{C}$. Energy \& Fuels, 22: 4034-4038.

Hayashi, J.-i., Li, C-Z. 2004. In: Advances in the Science 
of Victorian Brown Coal, C-Z. Li, (ed.), Chapter 2, Elsevier, Oxford, UK.

James, E.F., Durrani, N.A. 1994. Geology and Coal Resources of the Thar Coal Field, Sindh Province Pakistan, US Geological Survey Open File Report, 94-167.

Klimenko, A.Y. 2009. Early ideas in underground coal gasification and their evolution. Energies, 2: 456-476.

$\mathrm{Li}, \mathrm{C}$.-Z. 2007. Some recent advances in the understanding of the pyrolysis and gasification behaviour of Victorian brown coal. Fuel, 86: 1664-1683.

Qader, S.A. 1985. Coal Science and Technology 8. Natural Gas Substitutes from Coal and Oil. Chapter 5, Oxford, New York, Tokyo, Japan.

Schafer, H.N.S. 1991. The Science of Victorian Brown Coal, R.A. Durie (ed.), Chapter 7, Butterworth, Oxford, UK.

Wood, B.J., Sancier, K.M. 1984. The mechanism of the catalytic gasification of coal char: A critical review. Catalysis Review Science Engineering, 26: 233-279. 